\title{
THE EFFECT OF WAGE ON PRIVATE SECURITY OFFICERS JOB SATISFACTION AND INTENTION TO QUIT: AN EMPIRICAL STUDY IN TURKEY
}

\author{
ÜCRETIN ÖZEL GÜVENLİK GÖREVLİLERINNIN İŞ DOYUMU VE İŞTEN AYRILMA \\ NIYETLERİ ÜZERINNE ETKİSI: TÜRKIYY'DE YAPILMIŞ AMPRIKK BİR ARAŞTIRMA
}

\section{Uğur DEMİRCí ${ }^{1}$ - Banu ERGEN ${ }^{2}$}

\begin{abstract}
The purpose of this study is to reveal whether there is a difference between job satisfaction and intention to quit levels of the private security officers in terms of the wage they receive in accordance with employment types (Public-Private sector). The population of the study includes the private security officers working in İstanbul. Random sampling was conducted in the study. As a result of the questionnaires carried out in the context of the quantitative paradigm, 6249 data were found analyzable. In this study, the job satisfaction scale, developed by Weiss et al. (1967), and the intent to quit scale, developed by Scott et al. (1999), were used. According to the results, there is a statistically significant difference between job satisfaction and intention to quit levels of the private security officers employed in the private sector at each wage category. However, although there is a statistically significant difference among intention to quit levels of private security officers employed in the public sector at each wage category, there is an only statistically significant difference in the maximum wage category regarding job satisfaction level.
\end{abstract}

Keywords: Private security, Job satisfaction, Intent to quit, Public-Private, Wage

$\ddot{\mathbf{O z}}$

$\mathrm{Bu}$ araştırmanın amacı özel güvenlik görevlilerinin iş doyumu ile işten ayrılma niyeti tutumlarında aldıkları ücrete göre farklılaşma olup olmadığını istihdam şekilleri (Kamu-Özel sektör) bağlamında test etmektir. Araştırmanın evrenini İstanbul'da çalışan özel güvenlik görevlileri oluşturmaktadır. Araştırmada tesadüfi örneklem kullanılmıştır. Nicel paradigma çerçevesinde gerçekleştirilen çalışmada uygulanan anket neticesinde analize uygun 6249 veri araştırmaya dahil edilmiştir. Araştırmada Weiss vd. (1967) tarafından geliştirilen Minnesota İş Doyum Ölçeği ve Scott vd. (1999) tarafından geliştirilen İşten Ayrılma Niyeti Ölçeği kullanılmıştır. Araştırma sonuçlarına göre, her kademe ücret artışında, özel sektörde istihdam edilen özel güvenlik görevlilerinin iş doyumu ve işten ayrılma niyetlerinde istatistiksel olarak anlamlı farklılık bulunmaktadır. Ancak, kamuda istihdam edilen özel güvenlik görevlilerinin işten ayrılma niyetlerinde her kademe ücret artışında istatistiksel olarak anlamlı farklılık bulunmasına rağmen, iş doyumlarında sadece en üst kademe ücret artışında istatistiksel olarak anlamlı fark bulunmaktadır.

Anahtar Kelimeler: Özel güvenlik, İş doyumu, İşten ayrılma niyeti, Kamu-Özel, Ücret

\footnotetext{
${ }^{1}$ Emniyet Genel Müdürlüğü, ugurdemirci@yahoo.com, Orcid: 0000-0002-4677-3477

2 Öğr.Gör.Dr., İstanbul Medeniyet Üniversitesi, banuergen@ gmail.com, Orcid: 0000-0002-1329-9975
} 


\section{INTRODUCTION}

Private security sector in Turkey is developing more and more every day, thus creating employment opportunities. Currently, over 310,000 private security officers are employed in this field both in the public and private sectors. Statistics show that the number of private security officers employed in this sector increases each year. Given the development of the private security industry in the world, the development of the sector is expected to continue in Turkey as well.

In Turkey, not only the number of people who work in this sector but also the number of people who are eligible to work as a private security ID card holder is also very high. There are over 1 million people who have private security ID cards, which shows the high labor supply in the sector. However, the wages of those employed in the sector are generally low. The workforce turnover rate is also stated high in the sector (TOBB, 2014).

There is a negative correlation between real turnover and job satisfaction (Mobley et al., 1979), but a positive relationship between intention to quit and job satisfaction (Jewell, 1998; Mobley, 1982; Steel and Ovalle, 1984). Additionally, according to the literature review, wage is effective on both job satisfaction (Salleh and Memmon, 2015; Ghiselli et al., 2001; Summers and Henfrix, 1991) and intention to quit (Tan and Waheed, 2011). Therefore, determining whether wage has an effect on private security officers' job satisfaction and intention to quit might help practitioners find a way to reduce turnover rate.

In addition, employees' attitudes towards job satisfaction and their intention to quit can be affected by various organizational factors. In the literature, it is stated that employees' job satisfaction and intention to quit may differ according to the sector they are employed in (Public-Private sector) (Demirci, 2019). Therefore, this study aims to seek answers to the question "Do employees' job satisfaction and intention to quit levels differ according to their wage status?" If they do, "does this difference occur with respect to job satisfaction and intention to quit levels of the employees who work in public and private sectors? The purpose of this study is to reveal whether there is a difference between the private security officers' job satisfaction and intention to quit levels in terms of the wage they receive in accordance with the types of employment (Public-Private sector). The study was conducted within the framework of the quantitative paradigm and it was determined as a causal comparison study. The population of the study includes the private security officers working in İstanbul. Random sampling was conducted in the study. As a result of the questionnaires, 6249 data were found analyzable. ANOVA and Tukey tests were used to analyze this data. According to the results, there is a statistically significant difference among job satisfaction and intention to quit levels of the private security officers employed in the private sector at each wage category. However, although there is a statistically significant difference among intention to quit levels of private security officers employed in the public sector at each wage category, there is an only statistically significant difference in the maximum wage category regarding job satisfaction level of them.

\section{CONCEPTUAL FRAMEWORK}

\section{Private Security Sector and Employment Status in Turkey}

The first legislation regulating the private security sector in Turkey was published in 1981. The Law No. 2495 on Maintaining the Protection and Establishing the Safety of Some Institutions generally includes statements for the protection of places of critical importance to the state. Although it was amended in 1992 and 1995, it still failed to meet the demands arisen in Turkey in parallel with the developments in the world (Gülcü, 2002:58). 
In order to meet the demands of the private security sector, the Law on Private Security Services was enacted in 2004. The private security sector started to grow in Turkey following the enactment of this law. The number of private security companies which was 15 in 2004 increased to 916 in 2011, and to 1429 in 2018. As of October 2018, the total number of private security officers working in the sector is 312.244 . Of those, 97.718 officers work in the public sector and 214.5126 officers work in the private sector. In addition to this, there are 1,122,255 people ready to work with a private security ID card (Demirci, 2019:1247). According to the 2015 report by COESS (2017), the private security sector in Turkey is financially worth more than 3 billion Euros. However, it is known that most of the employees in this sector receive minimum wage (Eren, 2016).

The Law No. 5188 authorizes the provision of private security services in two different ways. One way is that private security personnel are employed by an individual or within the body of an institution or an organization having a private security permit. The other way is that those with a private security permit hire the services of a subcontracting private security companies certificated by the Ministry of Interior. In addition, with a legislative amendment made in 2018, employment status was defined for the public sector. According to this amendment, public institutions can only employ a private security officer as a worker. The exception is given to municipalities. Municipalities can only be provided with this service via their own companies. Therefore, for the private security sector, there are 4 different employment status (Private-unit, private-subcontracting, public unit, public sub-contracting) in Turkey (Demirci, 2019:1250).

\section{Job Satisfaction}

Job satisfaction can be defined as the extent to which an employee is content with the rewards he or she gets out of his or her job, particularly in terms of intrinsic motivation (Statt, 2004:64). Job satisfaction is also defined as the affection or emotional response of the individual to his/her job depending on the result of comparing the outputs with what is required (Buitendach and Rothmann, 2009: 1). Vroom (1964) defines job satisfaction as affective orientations on the part of individuals toward work roles which they are presently occupying. According to Hoppock (1935:47) job satisfaction is as any combination of psychological, physiological and environmental circumstances that cause a person fairly to accept he is satisfied with his job. Meanwhile, positive and favorable attitudes towards the job indicate job satisfaction. Negative and unfavorable attitudes towards the job indicate job dissatisfaction (Armstrong, 2006: 264).

Many factors such as promotion possibilities, age, gender, security, leadership status, management style, wages, working conditions, appreciation, work conditions and the work itself affect job satisfaction (Furnham and Andreas-Chamorro, 2009; Okpara, 2006; Friday and Friday, 2003; Crossman and Abou -Zaki, 2003; Moynihan and Pandey, 2007; Savery, 1996; Lam, 1995; Centers and Bugental, 1966). Moreover, job satisfaction results in high organizational citizenship behavior (Foote et al. 2008), increased performance, increased productivity, increased motivation, high organizational commitment in employees (Şimşek et al., 2007: 71), high life satisfaction (Aydıntan and Koç, 2016) and increased job involvement (Nwankwo et al., 2016). On the other hand, job dissatisfaction can lead to turnover, absenteeism, tardiness, accidents, strikes, grievances and sabotages (Rue and Byaes, 2003).

\section{Intention to Quit}

Intention to quit can be defined as a conscious and deliberate desire to leave the organization (Tett and Meyer, 1993: 262). While Price (2001: 600) defines turnover as the movement of employees outside the organizational boundaries, Pepe (2010: 103) remarks that 
the turnover intention is the measure of likelihood that an employee will leave an organization. The idea of leaving the job comes before quitting the job (Zeytinoğlu et al., 2007: 34). However, the fact that the intention to quit turns into an actual quitting behavior takes place through a process that is influenced by many external, organizational and personal factors (Hom et al., 1992: 905). While external factors are those such as unemployment rate and alternative job opportunities, organizational factors include those such as management style, wage and reward. Also, personal factors affecting this process can be indicated as the factors such as age, personality and family (Cotton and Tuttle, 1986: 63-64). Moreover, a positive relationship was found between the intention to quit and turnover (Jewell, 1998; Mobley, 1982; Steel and Ovalle, 1984).

\section{Wage}

Wage is defined as the material and/or cash value it receives in return for the work performed by the labor force that provides intellectual and/or physical work (Benligiray, 2013: 162). The wage does not only consist of basic salary, but it also includes additional benefits, welfare benefits and performance fees paid for the labor. Wage is a determining factor in individual's standard of living, and it is an indicator of cost factor affecting the development of economy and social justice in society (Zaim, 1986; 182). In this context, wage is a multifaceted concept that can affect almost all areas of economic and social life. Therefore, wage is of particular importance to the state, society, employers, trade unions and employees (Benligiray, 2013: 164).

Considering the state and society, wage is important in terms of providing justice in the distribution of personal income, ensuring social peace, increasing social welfare, creating equal opportunities and ensuring economic stability. For the employers, wage is an important expenditure item. Wages in production enterprises rarely fall below $20 \%$ of total costs, but exceed $80 \%$ of total costs in service enterprises. On the other hand, the most important goal of the unions is to increase the welfare of their members. Therefore, they are considered successful depending on the rate of increase in wages they earn from the employers in negotiations. For this purpose, trade unions generally focus on wage increase in collective negotiations (Benligiray. 2013: 165).

There are economic, social and motivating aspects of wage for employees (Benligiray, 2013: 164). Wage is the basic tool that employees use to meet the needs of themselves and their dependents. It is of particular importance since it determines employees' economic power, especially if it is the only basic source of income for them. It is also considered important because it determines the status of the individual in the workplace and social life. Moreover, wage is regarded as the most successful tool to motivate employees (Salleh \& Memon, 2015: 345).

Along with all this, wage is related to the attitudes which are of great importance for the effectiveness and efficiency of organizations such as motivation (Rynes et. All., 2004), organizational commitment (Byington and Johnson, 1991), organizational justice (Ay et al., 2018), organizational citizenship behavior (Allen, 2006), job satisfaction (Herzberg, et al., 1957; Young et al., 2014) and intention to quit (Ghiselli, La Lopa, and Bai, 2001). It is also known that wage has an effect on absenteeism (Carraher et al., 2006) and low job performance (Bretz and Thomas, 1992).

\section{Relationship between Wage and Job Satisfaction}

When the literature is examined, it is understood that wage has a positive effect on job satisfaction (Herzberg et al., 1957; Hulin and Smith, 1965; Beutell and Wittig-Berman, 1999; 
Igalens and Roussel, 1999; Vieira, 2005; Diaz-Serrano and Vieira, 2005; Tan and Waheed, 2011; Parvin and Kabir, 2011; Yilmaz, 2014). However, there are also studies showing that there is a negative relationship between wage and job satisfaction (Young et al., 2014).

According to one of these studies, Beutell and Wittig-Berman (1999) state that there is a relationship between wage and job satisfaction and that an increase in wages leads to an increase in job satisfaction. In another study, Tan and Waheed (2011) report that there is a relationship between wage and job satisfaction and that the love of money has a mediating role in this relationship. Serrano (2005) found that low-paid workers had low job satisfaction and high-paid employees had high job satisfaction levels. On the other hand, Young et al. (2014) found a negative relationship between wage and job satisfaction. Based on the literature review, the first research hypothesis is formulated as follows:

H1. Job satisfaction level of private security officers varies according to the wage they receive.

On the other hand, many organizational factors are known to be effective on job satisfaction. In the literature, there are studies showing that employment type (Public-Private sector) is effective on job satisfaction (Demirci, 2019; Soysal and Tan, 2013; Meena and Dangayach, 2012; Thakur, 2007). In this respect, the second and third research hypotheses are formulated as follows:

H2. Job satisfaction level of private security officers who work in the public sector varies according to the wage they receive.

H3. Job satisfaction level of private security officers who work in the private sector varies according to the wage they receive.

\section{The Relationship between Wage and Intention to Quit}

Considering the literature review, it is seen that there is research showing the perception of wage level has a negative effect on intention to quit (Ghiselli, La Lopa and Bai, 2001; Summers and Henfrix, 1991). Also, there is a negative correlation between wage satisfaction and intention to quit (Singh and Loncar, 2010; Salleh and Memon, 2015). Singh and Loncar (2010) found that there was a negative relationship between wage satisfaction and intention to quit, but that the relationship was variable. On the other hand, there are studies showing that wage level does not have a direct, but an indirect effect on intention to quit (Lee et al., 2012). Based on the literature review, the fourth research hypothesis is formulated as follows:

H4. Intention to quit level of private security officers varies according to the wage they receive.

On the other hand, when the literature is examined, it is argued that employees' intention to quit are affected by many factors such as environmental, organizational and individual ones (Ceylan and Ulutürk, 2006). Possible job opportunities, unemployment, salary level, tenure opportunity, education opportunities and burnout (Lum et al., 1998: 306; Akova et al., 2015: 87; Tütüncü and Demir, 2003; Avc1 and Küçükusta, 2009: 37) can be counted among these factors. For this reason, employment types can be considered to have an effect on individuals' intention to quit. There are studies confirming this hypothesis in the literature (Demirci, 2019; Çelik \& Yıldız, 2018; Wang, Yang and Wang: 2012). However, there are also studies showing that there is no difference between the public and private sector employees regarding their intention to quit (Sipahi and Kartal, 2018). In this respect, the fifth and sixth research hypotheses are formulated as follows: 
H5. Intention to quit level of private security officers who work in the public sector varies according to the wage they receive.

H6.Intention to quit level of private security officers who work in the private sector varies according to the wage they receive.

\section{METHOD}

\section{Purpose and Model of the Study}

The purpose of this study is to reveal whether there is a difference between the private security officers' job satisfaction and intention to quit levels in terms of the wage they receive in accordance with the types of employment (Public-Private sector). The study, which was conducted within the framework of the quantitative paradigm, was determined as a causal comparison study. A causal comparison study is a research to identify the causes of an existing or naturally occurring condition or event, and the variables that affect them, or the consequences of an effect (Büyüköztürk et. all., 2008:182; Başol, 2008: 15). In causal comparison studies, there are at least two groups that are affected by the same situation in different ways, or two groups that are affected by the supposed situation, and these groups are examined for some variables in order to determine the possible causes and effects of the current situation (Cohen and Manion, 1994). In causal comparison studies, unlike experimental research, investigated situation emerges independently from the manipulation of the researcher. The researcher tries to identify the possible causes and effects of this emerging situation (Büyüköztürk et. all., 2008; Cohen and Manion, 1994).

For this purpose, a questionnaire with relevant scales was applied to the private security officers working in Istanbul to determine their job satisfaction and intention to quit levels. As a result of the questionnaires, 6249 data were found analyzable. In addition, the following model was prepared based on the literature review.

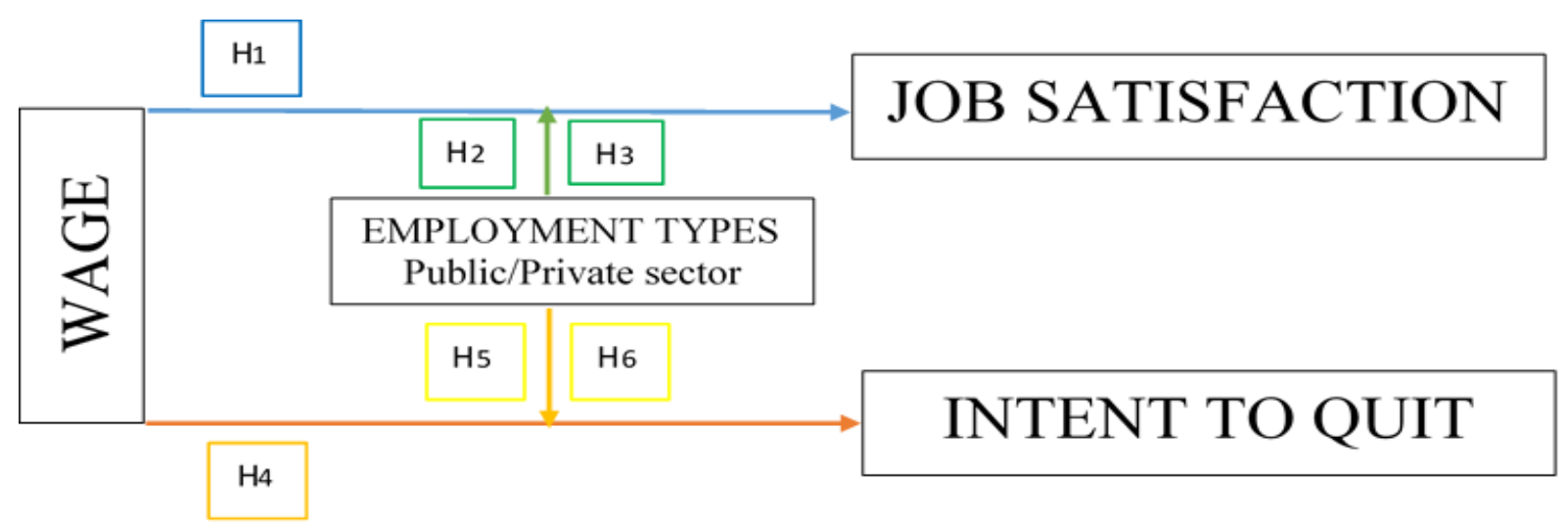

Figure 2. Model

\section{Population and Sample of the Study}

The research population is composed of private security officers working in Istanbul. As of October 2018, the number of private security officers working in Istanbul is 83,454 . Of these, 26,014 work in the public sector and 57,440 work in the private sector. 12.084 of the private security personnel working in the private sector work in units, while 45.356 work for various private security companies. 75.545 of the private security officers working in Istanbul are male and 7.909 are female. 
Table 1. Public-Private Distribution of Private Security Officers Working in İstanbul

\begin{tabular}{|c|c|c|}
\hline \multirow{2}{*}{$\begin{array}{c}\text { Private security officers } \\
\text { working in the public sector }\end{array}$} & \multicolumn{2}{|c|}{ Private security officers working in the private sector } \\
\hline & Unit & Sub-contracting \\
\hline \multirow[t]{2}{*}{26.014} & 12.084 & 45.356 \\
\hline & \multicolumn{2}{|c|}{57.440} \\
\hline
\end{tabular}

\subsection{4}

Random sampling method was used in the study. The questionnaire, which was prepared online, was sent to all public and private security unit managers and private security company managers in Istanbul in early October 2018. It was aimed to reach the population in a neutral manner by means of requesting supervisors to email the questionnaire to all private security officers in Istanbul. Meanwhile, participant responses were checked on a daily basis. The answers were discussed within the framework of the above mentioned and naturally occurring quotas (public-private / unit-subcontracting) and 10 days after the first announcement, the research announcement was repeated for the second time. 6249 data were obtained when the questionnaire was closed at the end of October 2018.

\section{Data Collection Tool}

The questionnaire was used as a data collection tool. It was prepared using the Minnesota Job Satisfaction Scale, developed by Weiss et al. (1967), which aims to find out participants' job satisfaction level, and the Intention to Quit Scale, developed by Scott et al. (1999), which aims to find out participants' intention to quit level.

The Minnesota Job Satisfaction Scale was translated into Turkish by Oran (1989). The scale has two versions, one with 100 questions and the other with 20 questions. The reliability and validity of the scale were tested in a large number of studies (Ghiselli et al., 2001; Hançer and George, 2003; Sevimli and İşcan, 2005; Özdemir, 2006). The scale consists of two subdimensions which determine the level of internal, external and general satisfaction (Weiss et al. 1967: 4-5). In this study, the 20-item short form of the scale was used. The original reliability coefficient of the scale was 0,83 . The Cronbach Alpha value of the scale used in this study was 0.961 . As a result of the normality test, it was determined that all values were between $+1,5$ and $-1,5$. The results showed that the data exhibited normal distribution (Tabachnick and Fidell, 2013).

The intention to quit scale, which was developed by Scott et al. (1999), consists of totally four questions, including a reverse one. The scale used as a single factor is a scale that was translated into Turkish and tested for reliability and validity (Aylan, 2012). The original reliability coefficient of the scale was 0,83 . The Cronbach's alpha value of the scale used in this study was 0,829 . As a result of the normality test, it was determined that all values were between $+1,5$ and $-1,5$. The results showed that the data exhibited normal distribution (Tabachnick and Fidell, 2013).

The questionnaire consisted of 31 questions, 7 of which were related to the demographic information, 20 related to the Job Satisfaction Scale, and 4 related to the intention to quit scale.

\section{Data analysis}

ANOVA and Tukey tests were used to analyze the data. Variance analysis (ANOVA) is commonly used to compare more than two groups. ANOVA is used to determine whether there is a difference among the groups, and if any, which group or groups are different (Gündoğdu, 2014: 311). ANOVA tests whether the mean of more than two samples showing normal distribution comes from the population with the same mean value based on common 
variance (Özdamar, 2003). When there is a difference as a result of the ANOVA test, multiple comparison tests are used to determine which groups are different. One of the multiple comparison tests is Tukey test. This test is often preferred in research because it reveals even the smallest differences among the means (Gündoğdu, 2014: 311). This test can control the increase in trial errors as the number of groups in the trials increases (Clever and Scarisbrick, 2001; Mason et al., 2003).

\section{FINDINGS AND ANALYSIS}

\section{Demographics of Participants}

Demographics of participants are indicated in Table 2.

Table 2. Demographics of Participants

\begin{tabular}{|c|c|c|c|}
\hline & Demographics & $\mathbf{N}$ & $\%$ \\
\hline \multirow{2}{*}{ Gender } & Men & 5.692 & 91,1 \\
\hline & Women & 557 & 8,9 \\
\hline \multirow{4}{*}{ Age } & Between 18-23 & 265 & 4,2 \\
\hline & Between 24-29 & 1.392 & 22,3 \\
\hline & Between 30-35 & 2.265 & 36,2 \\
\hline & Between 36 and more & 2.327 & 37,2 \\
\hline \multirow{5}{*}{ Education } & Secondary school & 640 & 10,2 \\
\hline & High school & 4.374 & 70 \\
\hline & Two-year higher education & 764 & 12,2 \\
\hline & Graduate Bachelor degree & 461 & 7,4 \\
\hline & Postgraduate & 1 & 0,0 \\
\hline \multirow{4}{*}{ Tenure } & 1 year and less & 1.611 & 25,8 \\
\hline & Between 2-5 years & 1.853 & 29,7 \\
\hline & Between $6-10$ years & 1.645 & 26,3 \\
\hline & 11 years and more & 1.140 & 18,2 \\
\hline \multirow{2}{*}{ Employment } & Public & 2.147 & 34,4 \\
\hline & Private sector & 4.102 & 65,6 \\
\hline \multirow{4}{*}{ Wage } & Between 1.500-2.000 TL. & 2.939 & 47 \\
\hline & Between 2.001-2.500 TL. & 1.129 & 18,1 \\
\hline & Between 2.501-3.000 TL: & 659 & 10,5 \\
\hline & 3.001 and more & 1.522 & 24,4 \\
\hline
\end{tabular}

\section{Relationship between Wage and Job Satisfaction}

The analysis of whether there is a difference in job satisfaction according to the wage of all private security officers participating in the research is presented below.

Table 3. Descriptive Statistics Regarding Wage and Job Satisfaction Level of All Participants

\begin{tabular}{lccc}
\hline & N & Mean & Std. Deviation \\
\hline Between 1500-2000 & 2939 & 3,1088 & 0,93048 \\
\hline Between 2001-2500 & 1129 & 3,2022 & 0,91780 \\
\hline Between 2501-3000 & 659 & 3,4173 & 0,87124 \\
\hline 3001 and more & 1522 & 3,5480 & 0,77446 \\
\hline Total & 6249 & 3,2652 & 0,90515 \\
\hline
\end{tabular}


Table 4. One-Way ANOVA Test Results for Wage and Job Satisfaction of All Participants

\begin{tabular}{lccccc}
\hline & $\begin{array}{c}\text { Sum of } \\
\text { squares }\end{array}$ & Sd & $\begin{array}{c}\text { Mean } \\
\text { square }\end{array}$ & F & sig \\
\hline $\begin{array}{l}\text { Between } \\
\text { groups }\end{array}$ & 213,342 & 3 & 71,114 & 90,530 & 0,000 \\
\hline $\begin{array}{l}\text { Within } \\
\text { groups }\end{array}$ & 4905,657 & 6245 & 0,786 & & \\
\hline Total & 5119,000 & 6248 & & & \\
\hline
\end{tabular}

When Table 4 is examined, it is understood that there is a significant difference in the job satisfaction levels of the participants according to their wages $(f=90,530, p<, 01)$. The results of the Tukey test performed to determine the significant difference between the groups are presented below.

Table 5. Tukey Test Results for Wage and Job Satisfaction of All Participants

\begin{tabular}{clcc}
\hline & Variables of wage & Mean difference & sig \\
\hline \multirow{2}{*}{ Between1500-2000 } & Between 2001-2500 & $-0,09334$ & $0,014^{*}$ \\
\cline { 2 - 4 } & Between 2501-3000 & $-0,30847$ & $0,000^{*}$ \\
\cline { 2 - 4 } Between 2001-2500 & 3001 and more & $-0,43920$ & $0,000^{*}$ \\
\cline { 2 - 4 } & Between 1500-2000 & 0,09334 & $0,014^{*}$ \\
\cline { 2 - 4 } Between 2501-3000 & $-0,21513$ & $0,000^{*}$ \\
\cline { 2 - 4 } Between 2501-3000 & Be01 and more & $-0,34586$ & $0,000^{*}$ \\
\cline { 2 - 4 } & Between 1500-2000 & 0,30847 & $0,000^{*}$ \\
\cline { 2 - 4 } & Between 2001-2500 & 0,21513 & $0,000^{*}$ \\
\hline \multirow{2}{*}{3001 and more } & Between 1500-2000 & $-0,13073$ & $0,009^{*}$ \\
\cline { 2 - 4 } & Between 2001-2500 & 0,43920 & $0,000^{*}$ \\
\cline { 2 - 4 } & Between 2501-3000 & 0,1307586 & $0,009^{*}$ \\
\hline p<.05 & & &
\end{tabular}

When Table 5 is examined, the Tukey test results for all groups are found to be statistically significant $(\mathrm{p}<.05)$. When the mean scores in Table 1 are examined, it is understood that the level of job satisfaction increases as the wages of private security officers' increase. Therefore, the hypothesis $\mathrm{H} 1$ is accepted.

The analysis of whether there is a difference in the job satisfaction of the private security officers employed in the public sector is presented below.

Table 6. Descriptive Statistics Regarding Wage and Job Satisfaction Level of the Participants Working in Public Sector

\begin{tabular}{lccc}
\hline & N & Mean & Std. Deviation \\
\hline Between 1500-2000 & 173 & 3,2503 & 0,98858 \\
\hline Between 2001-2500 & 50 & 3,3860 & 0,88393 \\
\hline Between 2501-3000 & 491 & 3,3733 & 0,85377 \\
\hline 3001 and more & 1433 & 3,5485 & 0,77217 \\
\hline Total & 2147 & 3,4806 & 0,81895 \\
\hline
\end{tabular}


Table 7. One-Way ANOVA Test Results for Wage and Job Satisfaction of the Participants Working in Public Sector

\begin{tabular}{lccccc}
\hline & $\begin{array}{c}\text { Sum of } \\
\text { squares }\end{array}$ & Sd & $\begin{array}{c}\text { Mean } \\
\text { square }\end{array}$ & F & sig \\
\hline $\begin{array}{l}\text { Between } \\
\text { groups }\end{array}$ & 21,888 & 3 & 7,296 & 11,031 & 0,000 \\
\hline $\begin{array}{l}\text { Within } \\
\text { groups }\end{array}$ & 1417,380 & 2143 & 0,661 & & \\
\hline Total & 1439,268 & 2146 & & & \\
\hline
\end{tabular}

As Table 7 shows, there is a significant difference in the job satisfaction levels according to the wages of the public employees ( $f=11,031, p<, 01)$. The results of the Tukey Test performed to determine the significant difference between the groups are presented below.

Table 8. Tukey Test Results for Wage and Job Satisfaction of the Participants Working at Public

\begin{tabular}{llcc}
\hline & Variables of wage & Mean difference & sig \\
\hline \multirow{3}{*}{ Between 1500-2000 } & Between 2001-2500 & $-0,13571$ & 0,726 \\
\cline { 2 - 4 } & Between 2501-3000 & $-0,12303$ & 0,318 \\
\cline { 2 - 4 } Between 2001-2500 & 3001 and more & $-0,29825$ & $0,000^{*}$ \\
\cline { 2 - 4 } & Between 1500-2000 & 0,13571 & 0,726 \\
\cline { 2 - 4 } Between 2501-3000 & 0,01268 & 1,000 \\
\hline \multirow{3}{*}{ Between 2501-3000 } & 3001 and more & $-0,16253$ & 0,506 \\
\cline { 2 - 4 } & Between 1500-2000 & 0,12303 & 0,318 \\
\cline { 2 - 4 } 3001 and moen 2001-2500 & $-0,01268$ & 1,000 \\
\hline \multirow{2}{*}{ 3001 and more } & $-0,17521$ & $0,000^{*}$ \\
\cline { 2 - 4 } & Between 1500-2000 & 0,29825 & $0,000^{*}$ \\
\cline { 2 - 4 } & Between 2001-2500 & 0,16253 & $0,000^{*}$ \\
\cline { 2 - 4 } & Between 2501-3000 & 0,17521 & \\
\hline
\end{tabular}

$\mathrm{p}<.05$

As Table 8 shows, job satisfaction levels of those receiving only $3001 \mathrm{TL}$ and above differ statistically from job satisfaction levels of those receiving between 2501-3000 TL, and 1500-2000 TL ( $\mathrm{p}<.05)$. When the mean scores in Table 8 are examined, it is seen that the ones for job satisfaction of private security officers increase as their wages increase. However, it was determined that job satisfaction levels of the participants paid between 2501-3000 TL and 2001-2500 TL were not statistically different from the mean scores of those receiving lower wages. According to these results, it can be stated that unlike the other wage groups, only the highest wage rate has an effect on job satisfaction levels of the private security officers employed in the public sector. Thus, the hypothesis $\mathrm{H} 2$ is partially accepted.

The analysis of whether there is a difference regarding job satisfaction of the private security personnel in the private sector participating in the research is presented below. 
Table 9. Descriptive Statistics Regarding Wage and Job Satisfaction Levels of the Participants Working in The Private Sector

\begin{tabular}{lccc}
\hline & N & Mean & Std. Deviation \\
\hline Between 1500-2000 & 2766 & 3,1000 & 0,92620 \\
\hline Between 2001-2500 & 1079 & 3,1937 & 0,91885 \\
\hline Between 2501-3000 & 168 & 3,5458 & 0,91090 \\
\hline 3001 and more & 89 & 3,5399 & 0,81499 \\
\hline Total & 4102 & 3,1524 & 0,92750 \\
\hline
\end{tabular}

Table 10. One-Way ANOVA Test Results for Wage and Job Satisfaction of the Participants Working in The Private Sector

\begin{tabular}{lccccc}
\hline & $\begin{array}{c}\text { Sum of } \\
\text { squares }\end{array}$ & Sd & $\begin{array}{c}\text { Mean } \\
\text { square }\end{array}$ & F & sig \\
\hline $\begin{array}{l}\text { Between } \\
\text { groups }\end{array}$ & 48,804 & 3 & 16,268 & 19,162 & 0,000 \\
\hline Within group & 3479,099 & 4098 & 0,849 & & \\
\hline Total & 3527,903 & 4101 & & & \\
\hline
\end{tabular}

When Table 10 is examined, it is understood that there is a significant difference between job satisfaction and wage levels of the public employees ( $f=19,162, p<, 01$ ). The results of the Tukey Test performed to determine the significant difference between the groups are presented below.

Table 11: Tukey Test Results for Wage and Job Satisfaction of the Participants Working in The Private Sector

\begin{tabular}{llcc}
\hline & Variables of wage & Mean difference & sig \\
\hline \multirow{3}{*}{ Between 1500-2000 } & Between 2001-2500 & $-0,09367$ & $0,024^{*}$ \\
\cline { 2 - 4 } & Between 2501-3000 & $-0,44585$ & $0,000^{*}$ \\
\cline { 2 - 4 } Between 2001-2500 & 3001 and more & $-0,43991$ & $0,000^{*}$ \\
\cline { 2 - 4 } & Between 1500-2000 & 0,09367 & $0,024^{*}$ \\
\cline { 2 - 4 } Between 2501-3000 & $-0,35218$ & $0,000^{*}$ \\
\cline { 2 - 4 } Between 2501-3000 & B001 and more & $-0,34624$ & $0,004^{*}$ \\
\cline { 2 - 4 } & Between 1500-2000 & 0,44585 & $0,000^{*}$ \\
\cline { 2 - 4 } 30tween 2001-2500 & 0,35218 & $0,000^{*}$ \\
\cline { 2 - 4 } 3001 and more & Between 1500-2000 & 0,00595 & 0,000 \\
\cline { 2 - 4 } & Between 2001-2500 & 0,33991 & $0,000^{*}$ \\
\cline { 2 - 4 } & Between 2501-3000 & $-0,00595$ & 1,000 \\
\hline
\end{tabular}

$\mathrm{P}<.05$

When Table 11 is examined, it is seen that there is no significant difference between the participants who are paid between 2501-3000 TL and 3001 and over and that there is a statistical difference between all the other groups. When the mean scores in Table 9 are examined, it is understood that job satisfaction level of the private security officers increases as the wages they receive increase. Thus, in view of these results, the hypothesis H3 is accepted.

\section{The Relationship between Wage and Intention to Quit}

The analysis of whether there is a difference in the intention to quit level of all private security officers participating in the research according to their wages is presented below. 
Table 12. Descriptive Statistics Regarding Wage and Intention to Quit Level of All Participants

\begin{tabular}{lccc}
\hline & N & Mean & Std. Deviation \\
\hline Between 1500-2000 & 2939 & 2,9482 & 1,09937 \\
\hline Between 2001-2500 & 1129 & 2,8884 & 1,11563 \\
\hline Between 2501-3000 & 659 & 2,2989 & 0,97993 \\
\hline 3001 and more & 1522 & 2,0958 & 0,88023 \\
\hline Total & 6249 & 2,6613 & 1,10570 \\
\hline
\end{tabular}

Table 13. One-Way ANOVA Test Results for Wage and Intention to Quit of All Participants

\begin{tabular}{lccccc}
\hline & $\begin{array}{c}\text { Sum of } \\
\text { squares }\end{array}$ & Sd & $\begin{array}{c}\text { Mean } \\
\text { square }\end{array}$ & F & sig \\
\hline $\begin{array}{l}\text { Between } \\
\text { groups }\end{array}$ & 873,451 & 3 & 291,150 & 268,763 & 0,000 \\
\hline $\begin{array}{l}\text { Within } \\
\text { groups }\end{array}$ & 6765,203 & 6245 & 1,083 & & \\
\hline Total & 7638,654 & 6248 & & & \\
\hline
\end{tabular}

When Table 13 is examined, it is understood that there is a significant difference in the participants' intention to quit according to their wages $(\mathrm{f}=268,763, \mathrm{p}<, 01)$. The results of the Tukey Test conducted for the purpose of determining the significant difference between the groups are presented below.

Table 14. Tukey Test Results for Wage and Intention to Quit of All Participants

\begin{tabular}{clcc}
\hline & Variables of wage & Mean difference & sig \\
\hline \multirow{3}{*}{ Between 1500-2000 } & Between 2001-2500 & 0,05980 & 0,356 \\
\cline { 2 - 4 } & Between 2501-3000 & 0,64926 & $0,000^{*}$ \\
\cline { 2 - 4 } Between 2001-2500 & 3001 and more & 0,85243 & $0,000^{*}$ \\
\cline { 2 - 4 } & Between 1500-2000 & $-0,05980$ & 0,356 \\
\cline { 2 - 4 } Between 2501-3000 & 0,58946 & $0,000^{*}$ \\
\hline \multirow{3}{*}{ Between 2501-3000 } & 3001 and more & 0,79263 & $0,000^{*}$ \\
\cline { 2 - 4 } & Between 1500-2000 & $-0,64926$ & $0,000^{*}$ \\
\cline { 2 - 4 } & Between 2001-2500 & $-0,58946$ & $0,000^{*}$ \\
\hline \multirow{2}{*}{3001 and more } & Between 1500-2000 & 0,20318 & $0,000^{*}$ \\
\cline { 2 - 4 } & Between 2001-2500 & $-0,85243$ & $0,000^{*}$ \\
\cline { 2 - 4 } & Between 2501-3000 & $-0,79263$ & $0,000^{*}$ \\
\hline
\end{tabular}

$\mathrm{p}<.05$

As Table 14 shows, there is no significant difference in intention to quit between the participants who are paid 1500-2000 TL and 2001-2500 TL, but there is a statistically significant difference between all the other groups. When the mean scores in Table 13 are examined, it can be seen that there is a decrease in the intention to quit level of private security officers as the wages they receive increase. Thus, the hypothesis $\mathrm{H} 4$ is accepted in view of these results.

The analysis of whether there is a difference in the intention to quit level of the private security personnel in the public sector participating in the research is presented below. 
Table 15. Descriptive Statistics Regarding Wage and Intention to Quit Level of the Participants Working in The Public Sector

\begin{tabular}{lccc}
\hline & N & Mean & Std. Deviation \\
\hline Between 1500-2000 & 173 & 2,6344 & 1,11266 \\
\hline Between 2001-2500 & 50 & 2,5650 & 1,02868 \\
\hline Between 2501-3000 & 491 & 2,2042 & 0,91818 \\
\hline 3001 and more & 1433 & 2,0801 & 0,86980 \\
\hline Total & 2147 & 2,1644 & 0,92053 \\
\hline
\end{tabular}

Table 16. One-Way ANOVA Test Results for Wage and Intention to Quit of the Participants Working in The Public Sector

\begin{tabular}{lccccc}
\hline & $\begin{array}{c}\text { Sum of } \\
\text { squares }\end{array}$ & Sd & $\begin{array}{c}\text { Mean } \\
\text { square }\end{array}$ & F & sig \\
\hline $\begin{array}{l}\text { Between } \\
\text { groups }\end{array}$ & 57,205 & 3 & 19,068 & 23,201 & 0,000 \\
\hline $\begin{array}{l}\text { Within } \\
\text { groups }\end{array}$ & 1761,257 & 2143 & 0,822 & & \\
\hline Total & 1818,461 & 2146 & & & \\
\hline
\end{tabular}

When Table 16 is examined, it is understood that there is a significant difference in the intention to quit levels of the public employees according to their wages ( $f=23,201, p<, 01)$. The results of the Tukey Test performed to determine the significant difference between the groups are presented below.

Table 17. Tukey Test Results for Wage and Intention to Quit of the Participants Working in The Public Sector

\begin{tabular}{clcc}
\hline & Variables of wage & Mean difference & Sig \\
\hline \multirow{3}{*}{ Between 1500-2000 } & Between 2001-2500 & 0,06939 & 0,964 \\
\cline { 2 - 4 } & Between 2501-3000 & 0,43022 & $0,000^{*}$ \\
\cline { 2 - 4 } Between 2001-2500 & 3001 and more & 0,55432 & $0,000^{*}$ \\
\cline { 2 - 4 } & Between 1500-2000 & $-0,06939$ & 0,964 \\
\cline { 2 - 4 } & Between 2501-3000 & 0,36082 & $0,037^{*}$ \\
\cline { 2 - 4 } Between 2501-3000 & 3001 and more & 0,48492 & $0,001^{*}$ \\
\cline { 2 - 4 } & Between 1500-2000 & $-0,43022$ & $0,000^{*}$ \\
\cline { 2 - 4 } & Between 2001-2500 & $-0,36082$ & $0,037^{*}$ \\
\hline \multirow{2}{*}{3001 and more } & Between 1500-2000 & 0,12410 & $0,044^{*}$ \\
\cline { 2 - 4 } & Between 2001-2500 & $-0,55432$ & $0,000^{*}$ \\
\cline { 2 - 4 } & Between 2501-3000 & $-0,48492$ & $0,001^{*}$ \\
\hline
\end{tabular}

$\mathrm{p}<.05$

When Table 17 is examined, it is seen that there is no significant difference between the participants who are paid between 1500-2000 TL and between 2001-2500, but there is a statistically significant difference between all the other groups. When the mean scores in Table 16 are examined, it can be seen that there is a decrease in the intention to quit level of the private security officers working in the public sector as the wages they receive increase. Thus, the hypothesis H5 is accepted. 
The analysis of whether there is a difference in the intention to quit level of the private security personnel in the private sector who participated in the research is presented below.

Table 18. Descriptive Statistics Regarding Wage and Intention to Quit Level of the Participants Working in The Private Sector

\begin{tabular}{lccc}
\hline & N & Mean & Std. Deviation \\
\hline Between 1500-2000 & 2766 & 2,9678 & 1,09576 \\
\hline Between 2001-2500 & 1079 & 2,9034 & 1,11767 \\
\hline Between 2501-3000 & 168 & 2,5759 & 1,09837 \\
\hline 3001 and more & 89 & 2,3483 & 1,00610 \\
\hline Total & 4102 & 2,9214 & 1,10558 \\
\hline
\end{tabular}

Table 19 One-Way ANOVA Test Results for Wage and Intention to Quit of The Participants Working in The Private Sector

\begin{tabular}{lccccc}
\hline & $\begin{array}{c}\text { Sum of } \\
\text { squares }\end{array}$ & Sd & $\begin{array}{c}\text { Mean } \\
\text { square }\end{array}$ & F & Sig \\
\hline $\begin{array}{l}\text { Between } \\
\text { groups }\end{array}$ & 55,596 & 3 & 18,532 & 15,321 & 0,000 \\
\hline Within group & 4957,049 & 4098 & 1,210 & & \\
\hline Total & 5012,645 & 4101 & & & \\
\hline
\end{tabular}

When Table 19 is examined, it is understood that there is a significant difference in the intention to quit level of the participants employed in the private sector according to their wages ( $f=15,321, p<, 01)$. The results of the Tukey Test performed to determine the significant difference between the groups are presented below.

Table 20. Tukey Test Results for Wage and Intention to Quit of the Participants Working in The Private Sector

\begin{tabular}{clcc}
\hline & Variables of wage & Mean difference & Sig \\
\hline \multirow{3}{*}{ Between 1500-2000 } & Between 2001-2500 & 0,06444 & 0,360 \\
\cline { 2 - 4 } & Between 2501-3000 & 0,39193 & $0,000^{*}$ \\
\cline { 2 - 4 } Between 2001-2500 & 3001 and more & 0,61951 & $0,000^{*}$ \\
\cline { 2 - 4 } & Between 1500-2000 & $-0,06444$ & 0,360 \\
\cline { 2 - 4 } & Between 2501-3000 & 0,32749 & $0,002^{*}$ \\
\hline \multirow{3}{*}{ Between 2501-3000 } & 3001 and more & 0,55507 & $0,000^{*}$ \\
\cline { 2 - 4 } & Between 1500-2000 & $-0,39193$ & $0,000^{*}$ \\
\cline { 2 - 4 } & Between 2001-2500 & $-0,32749$ & $0,002^{*}$ \\
\hline \multirow{3}{*}{3001 and more } & Between 1500-2000 & $-0,22758$ & 0,391 \\
\cline { 2 - 4 } & Between 2001-2500 & $-0,61951$ & $0,000^{*}$ \\
\cline { 2 - 4 } & Between 2501-3000 & $-0,55507$ & $0,000^{*}$ \\
\hline
\end{tabular}

$\mathrm{p}<.05$

When Table 20 is examined, it is seen that there is no significant difference in the intention to quit between the participants who are paid between 1500-2000 TL and between 2001 and 2500 TL. Similarly, it is understood that there is no significant difference in the intention to quit between the participants who are paid between 2501-3000 TL and $3001 \mathrm{TL}$ and above. However, it is seen that there are significant differences in the intention to quit between the two couple groups with low wages and the high wages. When the averages in Table 18 are examined, it can be stated that private security officers employed in the private 
sector decreased their intention to quit as wages increased, but only the wages higher than $2501 \mathrm{TL}$ are significantly effective on the intention to quit level of the participants working in the private sector. According to these results, the hypothesis H6 is accepted.

\section{CONCLUSION AND DISCUSSION}

According to the results of the research conducted by Herzberg et al., 1957; Hulin and Smith, 1965; Beutell and Wittig-Berman, 1999; Igalens and Roussel, 1999; Serrano, 2005; Tan and Waheed, 2011; Parvin and Kabir, 2011; Y1lmaz in 2014, it was predicted that job satisfaction of private security officers would be different according to the wage they received. The results of our study confirm this hypothesis. As the wages of private security officers increase, their job satisfaction also increases. According to these results, wage seems to be an important determinant of job satisfaction for private security officers.

The study also tested whether job satisfaction of private security officers working in the public and private sectors is different. According to the results of the study, although each categorical increase in the wages of the private security officers working in the private sector has an effect on their job satisfaction, only the top level of wage (3001 and above) creates a significant difference regarding job satisfaction of private security officers who work in the public sector. In view of these results, it can be stated that although wage increase for private security officers working in the private sector is an important determinant in terms of job satisfaction, up to a certain extent, it does not have a significant impact on job satisfaction for private security officers working in the public sector. Therefore, it can be stated that there are some other factors affecting their job satisfaction. A sense of job safety for the private security officers working in the public sector may have been effective in obtaining these results.

According to the results of the research conducted by Ghiselli et al., 2001; Summers and Henfrix, 1991; Singh and Loncar, 2010; Salleh and Memon in 2015, it was predicted that private security officers' intention to quit level would be differentiated according to their wages. The results of our study confirm this hypothesis. Private security officers are less likely to quit as they receive more wage. According to these results, wage seems to be an important determinant of intention to quit for private security officers.

The study also tested whether the intention to quit of private security officers working in the public and private sector is different. According to the results of the study, wages for private security officers working in both the public and private sectors seem to be an important determinant of their intention to quit.

Considering all these results, if private security units and private security companies which employ private security officers want to increase job satisfaction and decrease the intention to quit of their human resource, they should be aware of the fact that they need to take action by taking wages into account. However, open market conditions and the supply of high labor force are important determinants of wages paid to private security officers. The number of private security officers who have the potential to work in this sector is increasing day by day, thus leading to an easy labor substitution for the employer. This creates a vicious cycle. The low wages of private security officer, especially in the private sector, cause the shift in human resources to other sectors, albeit qualified, in case of a small wage increase. However, as the employer can substitute the employees easily, the wages are generally stay low in the sector. In order to avoid this vicious circle, measures must be taken to prevent the unqualifiedness of the private security service. Unskilled job requires unskilled labor. For this reason, it is considered that especially the high quality security service can be provided with qualified work force and it is evaluated that both the sector representatives and the State should take measures to prevent the private security service to be unqualified. In addition, all 
of these assessments also raise the question as to how professional the private security profession is in Turkey.

This study is limited to private security officers working in İstanbul. Since living conditions of İstanbul may differ from other provinces, research results conducted in other province or region may differ. On the other hand, it is known from the literature that many factors influence intention to quit. However, there are limited studies on the factors effecting private security officers' intention to quit level in Turkey. Hence, it will be useful to conduct studies to determine the factors effecting private security officers intention to quit level in Turkey.

\section{REFERENCES}

Akova, O., Tanrıverdi, H. \& Kahraman, O.C. (2015). Otel İşletmelerinde İşgören Devir Hızına Etki Eden Risk Faktörlerinin Belirlenmesine Yönelik Bir Araştırma. Süleyman Demirel Üniversitesi Vizyoner Dergisi, 6(12), 87-107.

Allen, T.D. (2006). Rewarding Good Citizens: The Relationship between Citizenship Behavior, Gender, and Organizational Rewards. Journal of Applied Social Psychology, 36 (1), 120-143.

Armstrong, M. (2006). A Handbook of Human Resource Management Practice, Tenth Edition, Kogan Page Publishing, London.

Avcı, N. \& Küçükusta, D. (2009). Konaklama İşletmelerinde Örgütsel Öğrenme, Örgütsel Bağlılık ve İşten Ayrılma Eğilimi Arasındaki İlişki. Anatolia: Turizm Araştırmaları Dergisi, 20(1), 33-44.

Ay, F., Ünal, Ö., Amarat, M. \& Hekim, S. (2018). İstihdam Şekillerine Göre Örgütsel Adalet Algılaması: Üniversite Hastanesi Örneği. İş ve Insan Dergisi, 5 (1), 33-46.

Aydıntan, B. \& Koç, H. (2016). The Relationship between Job Satisfaction and Life Satisfaction: An Empirical Study on Teachers. International Journal of Business and Social Science, 7 (10), 72-80.

Aylan, S. (2012). Organizasyonlarda Psikolojik Şiddet (Mobbing) ve İşten Ayrllma Niyeti Arasındaki İlişkiyi Tespit Etmeye Yönelik Konaklama Işsletmelerinde Bir Uygulama. (Unpublished Master Thesis). Ankara: Gazi Üniversitesi Eğitim Bilimleri Enstitüsü.

Başol, G. (2008). Bilimsel araştırma süreci ve yöntem. Kılıç, O. \& Cinoğlu, M. (Ed.). In. Bilimsel araştırma yöntemleri, ss.113-143. İstanbul: Lisans Yayıncılık.

Benligiray, S. (2013). İş Değerlemesi ve Ücret Yönetimi. (In: İnsan Kaynakları Yönetimi (Ed: R. Geylan ve H.Z. TONUS). Anadolu Üniversitesi Yayınları, yayın no: 2900. 156183.

Beutell, N. J. \& Wittig-Berman, U. (1999). Predictors of Work-Family Conflict and Satisfaction with Family, Job, Career, and Life. Psychological Reports,85(3), 893-903

Bretz, R.D. \& Thomas, S.L. (1992). Perceived Equity, Motivation, and Final-Offer Arbitration in Major League Baseball. Journal of Applied Psychology, 77, 280-287.

Buitendach, J. H. \& Rothmann, S. (2009). The Validation of the Minnesota Job Satisfaction Questionnaire in Selected Organizations in South Africa. SA Journal of Human Resource Management, 7 (1). 1-8. 
Büyüköztürk, Ş., Çakmak, E. , Akgün, Ö., Karadeniz, Ş. \& Demirel, F. (2008). Bilimsel Araştırma Yöntemleri. (1. Baskı). Ankara: Pegem Akademi.

Byington, J. R. \& Johnson, J. G. (1991). Influences on Turnover of Internal Auditors. Internal Auditing, 7 (2), 3-10.

Carraher, S.M., Gibson, J. \& Buckley, M. (2006). Compensation Satisfaction in the Baltics and the USA. Baltic Journal of Management, 1 (1), 7-23.

Çelik, M. \& Yıldız, B. (2018). Hemşirelerde Mesleki Bağlılık, Özdeşleşme ve İşten Ayrılma Niyeti İlişkisi: Kamu Sektörü ve Özel Sektör Karşılaştırması. Kastamonu Üniversitesi İktisadi ve İdari Bilimler Fakültesi Dergisi. 2(2), 47-75.

Centers, R. \& Bugental, P. (1966). Intrinsic and Extrinsic Job Motivations among Different Segments of the Working Population. Journal of Applied Psychology, 50, 193-197.

Ceylan, A. \& Ulutürk Y.H. (2006). Rol Belirsizliği, Rol Çatışması, İş Tatmini ve Performans Arasındaki İlişkiler. Doğuş Üniversitesi Dergisi, 7 (1), 48-58.

Clever, A.G. \& Scarisbrick, D. H. (2001). Practical Statistics and Experimental Design for Plant and Crop Science. John Wiley\&Sons Ltd., UK. ISBN: 0471899089.

COESS (2017). 2015 Report http://www.coess.org/newsroom.php?page=facts-and-figures . Access date: 01.03.2019

Cohen, L. \& Manion, L. (1994). Research Methods in Education (Fourth Edition), Routledge.

Cotton, J.L. \& Tuttle, J.M. (1986). Employee Turnover: A Meta-Analysis and Review with Implications for Research. The Academy of Management Review, 11(1), 55-70.

Crossman, A. \& Abou-Zaki, B. (2003). Job Satisfaction and Employee Performance of Lebanese Banking Staff. Journal of Managerial Psychology, 18(4), 368-376.

Demirci, U. (2019). İş Doyumu ile İşten Ayrılma Niyeti İlişkisine İstihdam Şekillerinin Etkisi. Uluslararası Sosyal Araştırmalar Dergisi, 12 (62), 1246-1258.

Diaz-Serrano, L. \& Vieira, J.A.C. (2005). Low-Pay Higher Pay and Job Satisfaction within The European Union Empirical Evidence From Fourteen Countries. IZA Discussion Paper, No. 1558. Available at SSRN: https://ssrn.com/abstract=702889

Eren, C. (2016). Özel Güvenlik Görevlilerinin Sorunları ve Sendikal Örgütlenme Deneyimi. Emek Araştırma Dergisi (GEAD), 7 (10), 117-154.

Foote, D.A., Li, T. \& Tang, T.L. (2008). Job Satisfaction and Organizational Citizenship Behavior (OCB) Does Team Commitment Make a Difference in Self-Directed Teams?. Management Decision, 46 (6), 933-947.

Friday, S.S. \& Friday, E. (2003). Racioethnic Perceptions of Job Characteristics and Job Satisfaction. Journal of Management Development, 22(5), 426-442.

Furnham, A. \& Andreas-Chamorro, P. T. (2009). Personality, Motivation and Job Satisfaction: Hertzberg Meets The Big Five. Journal of Managerial Psychology, 24 (8), 765-779.

Ghiselli, R., La Lopa, M. \& Bai, B. (2001). Job Satisfaction, Life Satisfaction, and Turnover Intent: Among Food-Service Managers. The Cornell Hotel and Restaurant Administration Quarterly, 42 (2)28-37.

Gülcü, M. (2002). Özel Güvenliğin Felsefesi (I). Polis Dergisi, 36, 58-70. 
Gündoğdu, S. (2014). Su Ürünlerinde Çoğunlukla Uygulanan Çoklu Karşılaştırma (POSTHOC) Testleri. Journal of Fisheries Sciences.com, 8 (4), 310-316.

Hançer, M. \& George, R. T. (2003). Job Satisfaction o Restaurant Employees: An Emprical Investigation Using The Minnesota Satisfaction Questionnaire. Journal of Hospitality\&Tourism Research, 27 (1), 85-100.

Herzberg, F. Mausner, B., Peterson, R. \& Capwell, D. (1957). Job Attitudes: Review of Research and Opinion. Oxford, England: Psychological Service of Pittsburgh.

Hom, P.W., Caranikas-Walker, F., Prussia, G.E. \& Griffeth, R.W. (1992). A Meta Analytical Structural Equations Analysis of a Model of Employee Turnover. Journal of Applied Psychology, 77(6), 890-909.

Hoppock, R. (1935). Job Satisfaction, Harper and Brothers, New York.

Hulin, C.L. \& Smith, P. (1965). A Linear Model of Job Satisfaction. Journal of Applied Psychology, 49, 209-216.

Igalens, J. \& Roussel, P. (1999). A study of The Relationships between Compensation Package, Work Motivation and Job Satisfaction. Journal of Organizational Behavior, 20, 1003-1025.

Jewell, L. N. (1998). Contemporary Industrial/Organizational Psychology. (3th ed.). Kaliforniya: Brooks/Cole Publishers.

Lam, S.S.K. (1995). Quality Management and Job Satisfaction: An Empirical Study. International Journal of Quality \& Reliability Management, 12(4), 72-78.

Lee, C., Huang, S. \& Zhao, C. (2012). A Study on Factors Affecting Turnover Intention of Hotel Employees. Asian Economic and Financial Review, 2 (7), 866-875.

Lum, L., Kervin, J., Clark, K. Reid, F. \& Sirola, W. (1998). Explaining Nursing Turnover Intent: Job Satisfaction, Pay Satisfaction, or Organizational Commitment?. Journal of Organizational Behavior, 19, 305-320.

Mason, R.L., Gunst, R.F. \& Hess, J.L. (2003). Statistical Design and Analysis of Experiments with Application to Engineering and Science. John Wiley\&Sons Publication, ISBN: 978047137216.

Meena, M.L. \& Dangayach, G.S. (2012). Analaysis of Employee Satisfaction in Banking Sector. International Journal of Humanities and Applied Sciences (IJHAS), 1 (2), 7881.

Mobley, W. H., Griffett, R. W., Hand, H. H. \& Meglino, B. M. (1979). Review and Conceptual Analysis of Employee Turnover Process. Psychological Bulletin, 86, s. 493-522

Mobley, W.H. (1982). Employee Turnover: Causes, Consequences, and Control. Massachusetts: Addison-Wesley Series on Managing Human Resources.

Moynihan, D.P. \& Pandey, S.K.(2007). Finding Workable Levers over Work Motivation: Comparing Job Satisfaction, Job Involvement, and Organizational Commitment. Administration and Society, 39 (7), 803-832.

Nwankwo, B., Agu, S., Sydney-Abor, N \& Chikwendu, C. (2016). The Relationship between Job Satisfaction and Job Involvement among Secondary School Teachers. International Journal of Case Studies, 3 (3), 2127. 
Okpara, J.O. (2006). The Relationship of Personal Characteristics and Job Satisfaction: A Study of Nigerian Managers in the Oil Industry. The Journal of American Academy of Business, 10 (1). 49-58.

Oran, N.B. (1989). A Study on Job Satisfaction of A Group of Academical Staff in Marmara University. (Unpublished Master Thesis). İstanbul: Marmara Üniversitesi Sosyal Bilimler Enstitüsü.

Özdamar, K. (2003). SPSS ile Bioistatistik. Eskişehir: Kaan Kitapevi. ISBN: 9756787074.

Özdemir, F. (2006). Örgütsel İklimin İş Tatmin Düzeyine Etkisi: Tekstil Sektöründe Bir Araştırma. (Unpublished Doctoral Thesis). Çukurova Üniversitesi Sosyal Bilimler Enstitüsü İşletme Anabilim Dalı.

Parvin, M.M. \& Kabir M.M.N. (2011). Factors Affecting Employee Job Satisfaction of Pharmaceutical Sector. Australian Journal of Business and Management Research, 1(9), 113-123.

Pepe, M. (2010). The Impact of Extrinsic Motivational Dissatisfiers on Employee Level of Job Satisfaction and Commitment Resulting in The Intent to Turnover. Journal of Business \& Economics Research, 8 (9), 99-108.

Price, J. 1. (2001). Reflections on The Determinants of Voluntary Turnover. International Journal of Manpower, 22 (7), 600-624.

Rue, L.W. \& Byars, L. (2003). Management, Skills and Application, 10th ed., McGrawHill/Irwin, New York.

Rynes, S.R., Gerhart, B. \& Minette, K.A. (2004). The Importance of Pay in Employee Motivation: Discrepancies between What People Say and What They Do. Human Resource Management, 43 (4), 381-394.

Salleh, R. \& Memon, M. A. (2015). A Review on The Effects of Pay Satisfaction on Employee Engagement and Turnover: A Proposed Mediating Framework. International Business Management, 9 (3), 344-348.

Savery, L.K. (1996). The Congruence between The Importance of Job Satisfaction and The Perceived Level of Achievement. Journal of Management Development, 15(6), 1827.

Scott C. R., Connaughton S. L., Diaz-Saenz H. R., Maguire K., Ramirez R., Richardson B., Shaw S. P. \& Morgan D. (1999). The Impacts of Communication and Multiple Identifications on Intent to Leave : A Multimethodological Exploration. Management Communication Quarterly. 12, 400 - 435.

Sevimli, F. \& İşcan, Ö.F. (2005). Bireysel ve İş Ortamına Ait Etkenler Açısından İş Doyumu. Ege Üniversitesi, İ.İ.B.F. Akademik Bakış Dergisi, 5 (1-2), 55-64.

Şimşek, M.Ş., Akgemci, T. \& Çelik, A., (2007) Davranış Bilimlerine Giriş ve Örgütlerde Davranış, Ankara

Singh, P. \& Loncar, N. (2010). Pay Satisfaction, Job Satisfaction and Turnover Intent. Industrial Relationship, 65 (3), 470-490.

Sipahi, H. \& Kartal, Y. (2018). Nepotizmin Örgütsel Sessizlik ve İșten Ayrılma Niyeti Üzerindeki Etkisi. İş̧ te Davranış Dergisi. 3(2), 109-118 
Soysal, A. \& Tan, M. (2013). İş Tatminini Etkileyen Faktörlerle İlgili Hizmet Sektöründe Yapılan Bir Araştırma: Kilis İli Kamu ve Özel Banka Personeli Örneği. Niğde Üniversitesi IIIBF Dergisi, 6 (2), 45-63.

Statt, D. (2004). The Routledge Dictionary of Business Management, Third edition, Routledge Publishing, Detroit.

Steel, R.P. \& Ovalle, N.K. (1984) A Review and Meta-Analysis of Research on The Relationship between Behavioral Intentions and Employee Turnover. Journal of Applied Psychology, 69(4), 673-686.

Summers, T.P. \& Hendrix, W. H. (1991). Modeling The Role of Pay Equity Perceptions: A Field Study. Journal of Occupational Psychology, 64 (1), 145-157.

Tabachnick, B.G. \& Fidell, L.S. (2013). Using Multivariate Statistics (6th ed.)Pearson, Boston.

Tan, T.H. \& Waheed, A. (2011). Herzberg's Motivation-Hygiene Theory and Job Satisfaction in the Malaysian Retail Sector: Mediating Effect of Love of Money. Asian Academy of Management Journal, 16. 73-94.

Tett, R. P. \& Meyer, J. P. (1993). Job Satisfaction, Organizational Commitment, Turnover Intention, and Turnover: Pathanalyses Based on Meta-Analytic Findings. Personnel Psychology, 46, 259-293.

Thakur, M., (2007). Job Satisfaction of Banking: A Study of Private and Public Sector Banks. The IUP Journal of Bank Management, 7 (4), 60-68.

TOBB (2014). Türkiye Özel Güvenlik Hizmetleri Meclisi Sektör Raporu. https://www.tobb.org.tr/Documents/ yayinlar/2014/ozel_guvenlik_meclisi_int.pdf . Access date: 01.03.2019

Tütüncü, Ö. \& Demir, M. (2003). Konaklama İşletmelerinde İnsan Kaynakları Kapsamında İşü̈cü Devir Hızının Analizi ve Muğla Bölgesi Örneği. Dokuz Eylül Üniversitesi Sosyal Bilimler Enstitüsü Dergisi, 5 (2), 146-169.

Vieira, J.A.C. (2005). Skill Mismatches and Job Satisfaction. Economic Letters, 89, 39-47.

Vroom, V.H. (1964). Work and Motivation, John Wiley and Sons, New York.

Wang, Y., Yang, C. \& Wang, K. (2012). Comparing Public and Private Employees' Job Satisfaction and Turnover. Public Personnel Management, 41(3), 557-573.

Weiss, D.J., Dawis, R.W., England, G.W. \& Lofquist, L.H. (1967). Manual for the Minnesota Satisfaction Quesitionnaire. http://vpr.psych.umn.edu/sites/g/files/pua2236/f/monograph xxii_manual_for_the_mn_satisfaction_questionnaire.pdf, Erişim tarihi: 15.11.2018.

Yılmaz, T. (2014). Çalışanların İş Tatmini ve Motivasyon Düzeyleri Arasındaki İlişkinin Incelenmesi: Kamu Çalışanları Üzerinde Bir Araştırma. (Unpublished master Thesis). Ankara: Gazi Üniversitesi, Eğitim Bilimleri Enstitüsü.

Young, L., Milner, M., Edmund, D., Pentsil, G. \& Broman, M. (2014). The Tenuous Relationship between Salary and Satisfaction. Journal of Behavioral Studies in Business, 7, 1-9.

Zaim S. (1986). Çalışma Ekonomisi. İstanbul: Filiz Kitabevi. 
Zeytinoğlu, I. U., Denton, M., Davies, S., Baumann, A., Blythe, J. \& Boos, L. (2007). Deteriorated External Work Environment, Heavy Workload and Nurses' Job Satisfaction and Turnover Intention. Canadian Public Policy, 33(1), 31-47. 